\title{
ANALISIS PEMELIHARAAN MESIN PRODUKSI PADA PT. HAYCARB PALU MITRA
}

\author{
Nandhika Dwi Putra I \\ Husein Hi. Moh Saleh \\ Asngadi \\ Program Studi S1 Manajemen, Fakultas Ekonomi, Universitas Tadulako \\ E-mail: nandikadwi69@gmail.com, asngady@yahoo.com, huseinsaleh868@ gmail.com
}

\begin{abstract}
This study aims to determine and analyze the maintenance of production machinery conducted PT. Haycarb Palu Partners and find out whether the policies carried out are efficient. To achieve these objectives, using statistical and mathematical quantitative methods as a tool to help decide the maintenance policy to be taken at a certain time period. The results showed that, using preventive maintenance policy on bucket elevators and rotary screnes, the lowest preventive maintenance cost (minimum) for the bucket elevators machine occurred in the 10th month of Rp.2.994. 200, -, and for the rotary screnes machine the lowest preventive maintenance cost (minimum) at month 9 is Rp.1.398.080.-. Measurement of technical efficiency, maintenance cost policy for bucket elevators machine at month six that is equal to Rp.3.675.500, , and for maintenance cost during the year is Rp.7.351.000, -. As for rotary screnes machine maintenance cost in the sixth month that is Rp.1.589.387 and for maintenance cost for a year of Rp.3.178.774, -, then PT. Haycarb Palu Partners can implement preventive maintenance that can save costs. Keywords: Maintenance, Preventive, Corrective, Efficiency
\end{abstract}

Penelitian ini bertujuan untuk mengetahui dan menganalisis pemeliharaan mesin produksi yang dilakukan PT. Haycarb Palu Mitra serta mengetahui apakah kebijakan yang dilakukan sudah efisien. Agar mencapai tujuan tersebut, dengan menggunakan metode kuantitatif statistik dan matematik sebagai alat untuk membantu memutuskan kebijakan pemeliharaan yang akan diambil pada suatu jangka waktu tertentu. Hasil penelitian menunjukkan bahwa, dengan menggunakan metode kebijakan pemeliharaan preventif (preventive maintenance) pada mesin bucket elevators dan mesin screnes rotary, menghasilkan biaya pemeliharaan preventif yang paling rendah (minimum) untuk mesin bucket elevators terjadi pada bulan ke-10 yaitu sebesar Rp.2.994.200,- , dan untuk mesin screnes rotary biaya pemeliharaan preventifnya yang paling rendah (minimum) pada bulan ke-9 yaitu sebesar Rp.1.398.080.-. Pengukuran efisiensi secara teknis, kebijakan biaya pemeliharaan untuk mesin bucket elevators pada bulan ke enam yaitu sebesar Rp.3.675.500,-, dan untuk biaya pemeliharaan selama setahunnya adalah Rp.7.351.000,-. Sedangkan untuk mesin screnes rotary biaya pemeliharaan pada bulan ke enam yaitu sebesar Rp.1.589.387 dan untuk biaya pemeliharaan selama setahunnya sebesar Rp.3.178.774,-, Maka PT. Haycarb Palu Mitra dapat menerapkan pemeliharaan preventif yang dapat mengemat biaya.

Kata Kunci: Pemeliharaan, Preventif, Korektif, Efisiensi

\section{PENDAHULUAN}

Industri manufaktur merupakan sumber yang memproduksi dan menyediakan produk yang dibutuhkan oleh masyarakat luas. Oleh karena itu, perusahaan harus mampu meningkatkan kualitas produksinya dan diikuti dengan teknologi mesin yang canggih. Perkembangan teknologi pada mesin industri yang semakin meningkat mendorong perusahaan industri mengeluarkan biaya investasi yang tidak sedikit agar dapat mengadopsi teknologi tersebut untuk menghasilkan produk yang berkualitas. Salah satu faktor produksi yang harus dioptimalkan penggunaannya yaitu mesin produksi. Mesin yang digunakan dalam kegiatan produksi harus mampu beroperasi dengan optimal.

Mesin dan peralatan yang berkondisi baik sangat menunjang untuk menghasilkan barang dan jasa yang berkualitas. Bagi sebuah perusahaan, usaha dalam menjaga kesiapan mesin agar tetap terjaga dan tetap kontinuitas, maka dibutuhkan perawatan dan pemeliharaan terhadap mesin-mesin dan peralatan secara teratur. Pemeliharaan (maintenance) yang baik akan menjaga konsistensi produksi sehingga perusahaan dapat menjaga kapasitas produksi sesuai target. Agar dapat menjamin pengoperasian mesin yang optimal, diperlukan suatu sistem perawatan dan pemeliharaan mesin yang tepat. 
Suatu perencanaan produksi dapat gagal apabila ada bagian mesin yang rusak atau tidak dapat beroperasi. Oleh karena itu, perencanaan perawatan (maintenance) mesin merupakan salah satu kegiatan yang sangat penting dalam operasi perusahaan manufaktur. (Prawirosentono,2007:314). Pemeliharaan pabrik dan peralatan dalam tatanan kerja yang baik sangat penting untuk mencapai tingkat kualitas dan keterandalan tertentu serta kerja yang efisien. Peralatan yang paling baik pun tidak akan bekerja secara memuaskan tanpa pemeliharaan. (Yamit,2003:394).

PT. Haycarb Palu Mitra merupakan salah satu perusahaan manufaktur yang berada di provinsi Sulawesi Tengah. PT. Haycarb Palu Mitra mulai berdiri pada tahun 2013 dan mulai melakukan proses produksi karbon aktif pada bulan Maret tahun 2014. PT. Haycarb Palu Mitra ini merupakan anak perusahaan dari Haycarb PLC yang berdiri sejak tahun 1973 yang berada di Sri Lanka. Perusahaan yang berasal dari Sri Lanka ini bergerak dalam industri global yang memproduksi karbon aktif yang berbahan dasar bahan baku arang tempurung kelapa.

Jenis mesin yang sering terjadinya kerusakan dari 11 jenis mesin tersebut adalah jenis mesin yang berada pada proses pre activation yaitu mesin bucket elevators dan mesin screnes rotary. Adapun salah satu faktor penyebab kerusakan dari kedua jenis mesin ini adalah, pola proses produksi yang dilakukan oleh perusahaan, dimana mesin yang secara terus-menerus beroperasi selama 24 jam penuh, sehingga mengakibatkan mesin mengalami kerusakan yang tidak terduga.

\section{KAJIAN LITERATURE DAN PENGEMBANGAN HIPOTESIS}

Menurut Chase et all (2006:6), manajemen operasi didefinisikan sebagai desain, operasi, dan peningkatan sistem yang menciptakan dan mendistribusikan produk dan jasa perusahaan. Assauri (2016:6) menyatakan bahwa manajemen operasi adalah kumpulan kegiatan yang berkaitan dengan penciptaan nilai dari barang dan jasa, dan gagasan, dengan mentransformasikan input menjadi output.

Sejalan dengan pengertian di atas, dapat diartikan bahwa manajemen operasi merupakan pengelolaan sumber daya yang dimiliki suatu perusahaan atau organisasi dalam menciptakan suatu barang atau jasa dengan perencanaan, pengoperasian dan peningkatan terhadap proses operasi. Sehingga tercipta sebuah pemikiran tentang bagaimana optimalisasi dari input-produksi-output, atau input-transformasi-output, dengan menggunakan sumber daya yang dimiliki perusahaan atau organisasi itu sendiri sehingga ruang lingkup manajemen operasi begitu luas karena mencakup bidang manufaktur dan jasa.

Menurut Assauri (2008:134) pemeliharaan adalah suatu kegiatan untuk memelihara atau menjaga fasilitas/peralatan pabrik dan mengadakan perbaikan atau penggantian yang diperlukan agar terdapat suatu pengadaan operasi produksi yang memuaskan sesuai dengan apa yang direncanakan. Menurut Mobley (2008:17) pemeliharaan merupakan fungsi yang penting dalam suatu pabrik. Sebagai suatu usaha menggunakan fasilitas/peralatan produksi agar kontinuitas produksi dapat terjamin dan menciptakan suatu keadaan operasi produksi yang memuaskan sesuai dengan rencana. Selain itu, fasilitas/peralatan produksi tersebut tidak mengalami kerusakan selama dipergunakan sebelum jangka waktu tertentu yang direncanakan tercapai.

Senada halnya dengan pengertian di atas, dapat disimpulkan bahwa pemeliharaan adalah suatu kegiatan yang dilakukan untuk memelihara fasilitas/peralatan produksi dan mengadakan perbaikan agar kontinuitas produksi dapat terjamin dan memuaskan sesuai dengan yang direncanakan, selain itu agar fasilitas mempunyai umur ekonomis yang panjang.

Menurut Assauri (2008:134) tujuan utama fungsi pemeliharaan adalah:

1. Kemampuan produksi dapat memenuhi kebutuhan sesuai dengan rencana produksi.

2. Menjaga kualitas pada tingkat yang tepat untuk memenuhi apa yang dibutuhkan oleh produk itu sendiri dan kegiatan produksi yang tidak terganggu.

3. Untuk membantu mengurangi pemakaian dan penyimpanan yang diluar batas dan menjaga modal yang diinvestasikan dalam perusahaan selama waktu yang ditentukan sesuai dengan kebijaksanaan perusahaan mengenai investasi tersebut.

4. Untuk mencapai tingkat biaya pemeliharaan serendah mungkin, dengan melaksanakan kegiatan maintenance secara efektif dan efesiensi keseluruhannya.

5. Menghindari kegiatan maintenance yang dapat membahayakan keselamatan para pekerja. 
6. Mengadakan suatu kerja sama yang erat dengan fungsi-fungsi utama lainnya dari suatu perusahaan dalam rangka untuk mencapai tujuan utama perusahaan, yaitu tingkat keuntungan atau return of investment yang sebaik mungkin dan total biaya yang terendah.

Menurut Prawirosentono (2007:331) strategi perawatan pemeliharaan mesin dapat dibagi menjadi berikut:

\section{Strategi Perawatan Berencana}

Strategi perawatan berencana meliputi kegiatan perawatan dalam berbagai keadaan yang diantaranya ialah pada waktu proses produksi sedang berjalan, yakni dengan selalu memantau seluruh mesin dan peralatan produksi, dan juga perawatan dilakukan pada waktu proses proses produksi sedang dihentikan

2. Strategi perawatan pencegahan

Strategi perawatan pencegahan merupakan kegiatan perawatan yang bersifat mencegah terjadi gangguan pada proses yang sedang berjalan. Perawatan ini untuk mencegah sering terjadinya kerusakan mesin, agar proses produksi dapat berjalan seoptimal mungkin. Strategi perawatan pencegahan akan segera tampak hasilnya berupa efisiensi karena terhindar dari kemacetan produksi akibat kerusakan salah satu mesin. Disamping itu, lancarnya penyediaan barang jadi berimpilkasi atas hubungan antara perusahaan dengan pasar (konsumen).

3. Strategi perawatan peramalan

Tujuan utama dari peramalan dalam manajemen perawatan adalah untuk meramalkan demand dari itemitem independent demand dimasa yang akan datang. Cara yang digunakan dengan mengkombinasikan dengan pelayanan pesanan-pesanan (order service) yang bersifat pasti, total permintaan dari suatu item atau produk dapat diketahui agar memudahkan manajemen produksi dan inventory.

4. Strategi Perawatan Darurat

Adapun tujuan dari perawatan darurat adalah antara lain untuk menanggulangi keadaan darurat. Misalnya, salah satu mesin yang sedang beroperasi tiba-tiba mogok karena rusak. Mesin ini secara darurat harus diperbaiki.

5. Strategi pengukuran kerja para tenaga perawat mesin

Pengukuran kinerja (performance measures) dapat dilakukan dengan menggunakan sistem penilaian (rating) yang relevan. Rating tersebut harus mudah digunakan sesuai dengan apa yang diukur, dan mencerminkan hal-hal yang memang menentukan kinerja. Pengukuran kinerja juga berarti membandingkan antara standar yang telah ditetapkan dengan kinerja yang sebenarnya terjadi.

Selanjutnya kapan atau seberapa sering aset harus dipelihara, Prawirosentono (2007:333) menjelaskan jadwal dan program pemeliharaan mesin yaitu sebagai berikut:

1. Jadwal perawatan, adalah pengaturan waktu kegiatan pemeliharaan mesin yang berkaitan dengan kegiatan proses produksi. Adapun hal yang perlu dalam penyusunan jadwal perawatan adalah:

a. Pembagian waktu perawatan untuk masing masing petugas dan koordinasi kerja dengan unit lain,

b. Alokasi tenaga maintenance dengan jadwal kerja produksi yang tepat.

2. Program pemeliharaan, merupakan daftar alokasi kegiatan perawatan mesin yang berisi jadwal waktu pelaksanaan kegiatan dan alokasi petugas. Program perawatan tersebut dibuat setiap minggu atau setiap bulan, atau periode waktu tertentu sesuai dengan kebutuhan produksi seperti menyediakan peralatan yang akan digunakan dalam pemeliharaan dan menganalisis serta memeriksa hasil pekerjaan perawatan yang telah dilaksanakan secara rutin.

Menurut Sukirno (2006:257) efisiensi dalam konsep produksi terbatas pada melihat hubungan teknis dan operasional dalam suatu proses produksi, yaitu konversi input menjadi output. Sedangkan efisiensi ekonomi melihat secara luas pada pengalokasian sumber-sumber daya di dalam suatu perekonomian yang mendatangkan kesejahteraan di dalam masyarakat. Menurut Sukirno (2006:257) penggunaan sumber-sumber daya bisa dikatakan efisien apabila:

a. Seluruh sumber-sumber daya yang tersedia sepenuhnya digunakan.

b. Corak penggunaannya adalah sudah sedemikian rupa sehingga tidak terdapat lagi corak penggunaan lain yang akan memberikan tambahan kemakmuran bagi masyarakat/individu.

Menurut Assauri (2008:140) perbandingan biaya yang perlu dilakukan antara lain untuk menentukan:

1. Apakah sebaiknya preventive maintenance atau corrective maintenance saja. Dalam hal ini, biaya yang diperlukan adalah: 
a. Jumlah biaya yang diperlukan akibat kerusakan yang terjadi akibat tidak adanya preventive maintenance, dengan jumlah biaya pemeliharaan dan perbaikan yang diperlukan akibat kerusakan yang terjadi walaupun telah diadakan preventive maintenance, dalam satu jangka tertentu.

b. Jumlah biaya pemeliharaan dan perbaikan yang akan dilakukan terhadap suatu peralatan dengan harga peralatan tersebut.

c. Jumlah biaya pemeliharaan dan perbaikan yang dibutuhkan oleh suatu perawatan dengan jumlah kerugian yang akan dihadapi apabila peralatan tersebut rusak dalam operasi produksi.

2. Apakah peralatan yang rusak diperbaiki didalam perusahaan atau diluar. Biaya-biaya yang perlu diperbandingan adalah jumlah biaya yang keluar untuk memperbaiki peralatan tersebut di bengkel perusahaan sendiri dengan jumlah perbaikan pada bengkel perusahaan lain, disamping kualitas dan lamanya waktu yang dibutuhkan untuk pengerjaannya.

3. Apakah peralatan yang rusak diperbaiki atau diganti. Hal ini menyangkut biaya-biaya yang perlu dibandingkan adalah:

a. Jumlah biaya perbaikan dengan harga pasar atau nilai dari peralatan tersebut

b. Jumlah biaya perbaikan dengan harga peralatan yang sama dipasar.

Berdasarkan keterangan di atas dapat diambil kesimpulan bahwa secara teknis, preventive maintenance penting dan perlu dilaksanakan untuk menjamin kelancaran bekerjanya suatu mesin atau peralatan. Namun, secara ekonomis belum tentu selamanya preventive maintenance yang terbaik dan perlu diadakan untuk setiap mesin dan peralatan. Sebab dalam menentukan mana yang terbaik secara ekonomis harus dilihat faktor-faktor yang dapat mempengaruhi dan jumlah biaya yang akan terjadi.

Menurut Assauri (2008:137) didalam melaksanakan kegiatan maintenance, terdapat dua persoalan yang dihadapi oleh suatu perusahaan pabrik yaitu persoalan teknis dan persoalan ekonomis. Adapun yang merupakan persoalan teknis dalam hal ini adalah persoalan yang menyangkut usaha-usaha untuk menghilangkan kemungkinan-kemungkinan timbulnya kemacetan yang disebabkan karena kondisi fasilitas atau peralatan produksi tidak baik.

Tujuan yang akan dicapai dalam mengatasi persoalan teknis ini adalah untuk dapat menjaga atau menjamin agar produksi pabrik dapat berjalan lancar. Persoalan-persoalan teknis ini yang perlu diperhatikan untuk mencapai tingkat efisiensi adalah:

a. Tindakan-tindakan apa yang harus dilakukan untuk memelihara/merawat peralatan yang ada, dan untuk memperbaiki/mereparasi mesin-mesin atau peralatan yang rusak

b. Alat-alat atau komponen-komponen apa yang dibutuhkan dan harus disediakan agar tindakan-tindakan pada bagian pertama diatas dapat dilakukan.

Sudah tentu dalam melaksanakan kegiatan maintenance di samping persoalan teknis, ditemui pula persoalan ekonomis. Adapun yang merupakan persoalan ekonomis dalam hal ini adalah persoalan yang menyangkut bagaimana usaha yang harus dilakukan supaya kegiatan maintenance yang dibutuhkan secara teknis dapat efisien. Di dalam persoalan ekonomis ini, perlu diadakan analisis perbandingan biaya antara masing-masing alternatif tindakan yang dapat diambil. Adapun biaya-biaya yang terdapat dalam kegiatan maintenance adalah biaya-biaya pengecekan, dan penyetelan, biaya service, biaya penyesuaian (adjustment) dan biaya perbaikan/reparasi.

Hal ini makin intensif kegiatan pemeliharaan dilakukan berarti biayanya makin besar. Demikian pula makin besar skala/volume produksi makin banyak tenaga perawat mesin, karena banyak pula tahap kegiatan produksi perlu dimonitor. Jadi biaya pemeliharaan berbanding lurus dengan frekuensi pemeliharaan dan skala usaha. Adapun frekuensi perawatan mesin tergantung kepada kondisi mesin itu sendiri. Misalnya, mesin sering rusakan karena umurnya telah tua, berarti bukan saja perlu di pelihara lebih sering, namun perlu pula sering di monitor.

Menurut Assauri (2008:143) pelaksanaan kegiatan pemeliharaan dari peralatan disuatu perusahaan tergantung dari kebijaksanaan perusahaan itu yang kadang-kadang berbeda dengan kebijaksanaan perusahaan lainnya. Kebijaksanaan bagian pemeliharaan biasanya ditentukan oleh pimpinan tertinggi (top management) perusahaan.

Walaupun kebijaksanaan (policy) ditentukan, tetapi di dalam pelaksanaan kebijaksanaan tersebut manajer bagian pemeliharaan harus memperhatikan enam prasyarat agar pekerjaan bagian pemeliharaan dapat efisien. Keenam prasyarat tersebut adalah: 
1. Harus ada data mengenai mesin dan peralatan yang dimiliki perusahaan.

2. Harus ada planning dan scheduling

3. Harus ada surat perintah (work orders) yang tertulis

4. Harus ada persediaan alat-alat/spareparts (store control)

5. Harus ada catatan (records)

6. Harus ada laporan, pengawasan, dan analisis (reports,control, and analysis)

\section{METODE PENELITIAN}

Jenis penelitian ini merupakan jenis penelitian studi kasus yaitu penelitian yang dilakukan secara intensif, terinci dan mendalam terhadap objek suatu organisme, lembaga atau gejala-gejala tertentu yang diteliti. Arikunto (2006:115). Adapun studi kasus yang dibahas pada penelitian ini yaitu mengenai kebijakan pemeliharaan mesin produksi pada PT. Haycarb Palu Mitra.

Lokasi penelitian yang dimaksud dalam penelitian ini adalah PT. Haycarb Palu Mitra. Perusahaan ini beralamat di Jl. Moh Saleh, Taipa, Palu Utara. Alasan penelitian ini dilakukan di PT. Haycarb Palu Mitra dikarenakan PT. Haycarb Palu Mitra merupakan salah satu perusahaan industri manufaktur terbesar di dunia yang berasal dari Srilanka dan hanya memiliki 2 pabrik pengolahan arang tempurung kelapa menjadi karbon aktif di Indonesia, dan salah satunya berada di Provinsi Sulawesi Tengah.

\section{Data Kuantitatif}

Sugiyono (2014:13) mengemukakan bahwa metode penelitian kuantitatif merupakan metode penelitian yang berlandaskan pada filsafat positivisme, digunakan untuk meneliti pada populasi atau sampel tertentu.

Data kuantitatif adalah data terukur berupa angka-angka, jumlah maupun hasil perhitungan yang diperoleh langsung dari perusahaan yang akan diolah lebih lanjut secara sistematis.

2. Data Kualitatif

Sugiyono (2014:15) data kualitatif adalah data yang dinyatakan dalam bentuk kata, kalimat, dan gambar yang merujuk pada penelitian ini dengan masalah yang dibahas. Data kualitatif lebih bersifat deskriptif. Dalam penelitian ini, data kualitatif merupakan data yang terkumpul berbentuk kata-kata atau gambar sehingga tidak menekankan pada angka, seperti wawancara dan observasi.

Data penelitian ini membutuhkan data-data yang relevan untuk bisa menginformasikan masalah dan menyelesaikan masalah yang diteliti, sumber data yang diperlukan antara lain :

a. Data Primer

Sunyoto (2016:21) mengemukakan bahwa data primer adalah data asli yang dikumpulkan sendiri oleh peneliti untuk menjawab masalah penelitiannya secara khusus. Data primer yang didapatkan langsung pada PT. Haycarb Palu Mitra yaitu berupa jenis mesin dan biaya yang dikeluarkan oleh perusahaan dalam melakukan pemeliharaan mesin.

b. Data Sekunder

Sunyoto (2016:21) mendefenisikan, data sekunder adalah data yang bersumber dari catatan yang ada pada perusahaan dan dari sumber lainnya yaitu dengan mengadakan studi kepustakaan dengan mempelajari bukubuku yang ada hubungannya dengan obyek penelitian atau dapat dilakukan dengan menggunakan data dari Badan Pusat Statistik (BPS).

Adapun teknik pengumpulan data yang digunakan dalam penelitian ini terdiri dari:

1. Observasi

Sunyoto (2016:22) menyatakan bahwa metode observasi adalah suatu metode yang digunakan oleh peneliti dengan cara pengamatan langsung terhadap kegiatan yang dilaksanakan perusahaan. Pengamatan secara langsung dilakukan untuk mendapatkan data-data mengenai gambaran umum perusahaan, biaya yang mempengaruhi pemeliharaan mesin produksi dan data lalu yang berhubungan dengan permasalahan. Adapun objek observasi dari penelitian ini adalah mesin bucket elevators dan mesin screnes rotary.

2. Wawancara

Sunyoto (2016:22) mengemukakan bahwa metode wawancara adalah metode pengumpulan data dengan mengajukan pertanyaan-pertanyaan secara bebas baik terstruktur maupun tidak terstruktur dengan tujuan memperoleh informasi secara luas mengenai objek penelitian. Untuk mendapatkan data yang dibutuhkan dilakukan wawancara secara langsung kepada beberapa pihak, diantaranya: General Manager PT. Haycarb Palu Mitra, Engineering and Maintenance Manager dan Finance Executive PT. Haycarb Palu Mitra.

3. Metode Dokumentasi 
Dokumentasi yaitu metode pengumpulan data yang dilakukan dengan cara mengumpulkan dokumendokumen yang dianggap mempunyai hubungan dengan masalah yang diteliti.

Definisi operasional variabel dalam hal ini mencakup mengenai variabel yang telah dipilih ataupun mesin yang digunakan dalam proses produksi. Ini juga merupakan batasan yang digunakan untuk mempermudah pengumpulan data dan memperjelas ruang lingkup penelitian yaitu mengenai pemeliharaan. Definisi operasional variabel menjelaskan cara tertentu yang digunakan untuk meneliti dan mengoperasikan konstruk, sehingga memungkinkan bagi peneliti yang lain untuk melakukan replikasi pengukuran dengan cara yang sama atau mengembangkan cara pengukuran konstruk yang lebih baik.

Tujuan operasional variabel yaitu untuk memudahkan semua pihak-pihak yang terkait dalam penelitian ini agar mendapatkan keseragaman pemahaman. Maka peneliti memberikan pemaknaan dan penjabaran terhadap variabel-variabel penelitian dalam bentuk pendefinisian operasional variabel sebagai berikut:

1. Pemeliharaan

2. Pemeliharaan Pencegahan

3. Pemeliharaan Korektif

$$
B_{n+=} \mathrm{N} \sum_{1}^{n} P n+\mathrm{B}(\mathrm{n}-1) P_{1}+\mathrm{B}(\mathrm{n}-2) P_{2}+\ldots . .+B_{1} \mathrm{P}(\mathrm{n}-1)
$$

\section{HASIL DAN PEMBAHASAN}

Tabel 1. Perhitungan Untuk Mencari Jumlah Bulan yang Diperkirakan Antar Kerusakan

\begin{tabular}{|c|c|c|c|c|c|}
\hline \multicolumn{3}{|c|}{ Mesin Bucket Elevators } & \multicolumn{3}{c|}{ Mesin Screnes Rotary } \\
\hline $\begin{array}{c}\text { (a) } \\
\text { Probabilitas } \\
\text { terjadinya } \\
\text { kerusakan }\end{array}$ & $\begin{array}{c}\text { (b) } \\
\text { periode } \\
\text { antar } \\
\text { kerusakan }\end{array}$ & $(\mathrm{a}) \mathrm{x}(\mathrm{b})$ & $\begin{array}{c}\text { (a) } \\
\text { Probabilitas } \\
\text { terjadinya } \\
\text { kerusakan }\end{array}$ & $\begin{array}{c}\text { (b) } \\
\text { periode } \\
\text { antar } \\
\text { kerusakan }\end{array}$ & $(\mathrm{a}) \mathrm{x}(\mathrm{b})$ \\
\hline 0 & 0 & 0 & 0 & 0 & 0 \\
\hline 0 & 0 & 0 & 0.143 & 1 & 0.143 \\
\hline 0.33 & 2 & 0.66 & 0.286 & 2 & 0.57 \\
\hline 0 & 0 & 0 & 0.143 & 0 & 0 \\
\hline 0.167 & 1 & 0.167 & 0 & 0 & 0 \\
\hline 0 & 0 & 0 & 0 & 0 & 0 \\
\hline 0 & 0 & 0 & 0.143 & 1 & 0.143 \\
\hline 0.167 & 1 & 0.167 & 0.143 & 1 & 0.143 \\
\hline 0 & 0 & 0 & 0 & 0 & 0 \\
\hline 0 & 0 & 0 & 0 & 0 & 0 \\
\hline 0 & 0 & 0 & 0 & 0 & 0 \\
\hline 0.33 & 2 & 0.67 & 0.143 & 2 & 0.29 \\
\hline Jumlah & 6 & $\mathbf{1 . 6 6}$ & Jumlah & 7 & $\mathbf{1 . 2 8 7}$ \\
\hline
\end{tabular}

Berdasarkan perhitungan tabel 5 di atas, dapat diketahui bahwa untuk total biaya pemeliharaan korektif mesin bucket elevators sebesar Rp.13.855.000,- dan total biaya pemeliharaan korektif mesin screnes rotary sebesar Rp.6.763.015,- 
Tabel 6. Anggaran Biaya Pemeliharaan Perusahaan, Biaya Korektif pertahun dan Biaya Pemeliharaan Preventif pertahun Untuk Kedua Jenis Mesin

\begin{tabular}{|c|c|c|c|}
\hline Jenis Mesin & $\begin{array}{c}\text { Anggaran Biaya } \\
\text { Pemeliharaan } \\
\text { Perusahaan/tahun }\end{array}$ & $\begin{array}{c}\text { Biaya Korektif/ } \\
\text { tahun }\end{array}$ & $\begin{array}{c}\text { Biaya Pemeliharaan } \\
\text { Preventif/tahun }\end{array}$ \\
\hline Bucket Elevators & Rp.85.000.000,- & Rp.13.855.000,- & Rp.7.351.000,- \\
\hline Screnes Rotary & Rp.40.000.000,- & Rp.6.763.015,- & Rp.3.178.774,- \\
\hline
\end{tabular}

Merujuk pada tabel 6 di atas, peneliti menjabarkan mengenai anggaran biaya pemeliharaan yang dikeluarkan oleh perusahaan dalam setahun, yaitu untuk jenis mesin bucket elevators sebesar Rp.85.000.000,- dan untuk jenis mesin screnes rotary sebesar Rp.40.000.000,- . PT. Haycarb Palu Mitra menerapkan kebijakan pemeliharaan preventif pertahun dengan melakukan jadwal kegiatan pemeliharaan selama dua kali dalam setahun, artinya schedule untuk kegiatan pemeliharaan dilakukan setiap enam bulan sekali. Maka peneliti juga mengambil biaya sub kebijaksanaan pemeliharaan untuk mesin bucket elevators pada bulan ke enam yaitu sebesar Rp.3.675.500,- dan untuk biaya pemeliharaan selama setahunnya adalah Rp.7.351.000,-. Sedangkan untuk mesin screnes rotary biaya pemeliharaan pada bulan ke enam yaitu sebesar Rp.1.589.387 dan untuk biaya pemeliharaan selama setahunnya sebesar Rp.3.178.774,-.

\section{KESIMPULAN DAN SARAN}

Berdasarkan pembahasan dan analisis yang telah dikemukakan pada bab sebelumnya, maka peneliti dapat menarik suatu kesimpulan dari hasil penelitian tersebut, antara lain, dengan pengukuran efisiensi secara teknis, biaya kebijakan pemeliharaan mengikuti schedule perusahaan untuk mesin bucket elevators pada bulan ke enam yaitu sebesar Rp.3.675.500,-, dan untuk biaya pemeliharaan selama setahunnya adalah Rp.7.351.000,-. Untuk mesin screnes rotary biaya pemeliharaan pada bulan ke enam yaitu sebesar Rp.1.589.387 dan untuk biaya pemeliharaan selama setahunnya sebesar Rp.3.178.774,- . Penggunaan metode kebijakan pemeliharaan preventif (preventive maintenance) pada mesin bucket elevators dan mesin screnes rotary, menghasilkan biaya pemeliharaan preventif yang paling rendah (minimum) untuk mesin bucket elevators terjadi pada bulan ke-10 yaitu sebesar Rp.2.994.200,-dan untuk mesin screnes rotary biaya pemeliharaan preventifnya yang paling rendah (minimum) pada bulan ke-9 yaitu sebesar Rp.1.398.080.- , sehingga pemeliharaan secara preventif lebih mengefisienkan biaya pemeliharaan dibandingkan dengan pemeliharaan korektif.

Adapun saran yang diharapkan dari penulis bagi perusahaan adalah diharapkan kepada pihak PT. Haycarb Palu Mitra agar menerapkan kebijakan pemeliharaan preventif untuk kedua jenis mesin tersebut, agar dapat mengefisiensikan biaya pemeliharaan, diharapkan kepada PT. Haycarb Palu Mitra agar dapat melaksanakan manajamen pemeliharaan dengan baik, yang dimulai dengan perencanaan, pelaksanaan (penyimpanan dokumen teknis peralatan, dan pelaksanaan pemeliharaan) sampai dengan pelaporan dan evaluasi dan untuk melaksanakan program pemeliharaan preventif, diharapkan kepada PT. Haycarb Palu Mitra memerlukan tenaga kerja yang professional, memiliki etos kerja yang sangat tinggi, dan kelengkapan faktor pendukung seperti peralatan kerja (equipment) yang harus disediakan oleh perusahaan.

\section{REFERENSI}

Arikunto, 2006. Metode Penelitian Suatu pendekatan Proposal. Jakarta: PT. Rineke Cipta

Assauri, Sofjan. 2008. Manajemen Produksi dan Operasi. Jakarta: Lembaga Penerbit Fakultas Ekonomi Universitas Indonesia.

Assauri, Sofjan. 2016. Manajemen Operasi Produksi, Pencapaian Sasaran Organisasi Berkesinambungan. Jakarta: PT. Raja Grafindo Persada.

Chase, Aquilano, Jacobs, 2006. Operations Management for Competitive Advantage with Global Cases, Eleventh Edition, Mc Graw-Hill Companies,Inc., New York.

Mobley, R. Keith. 2008. Maintenance Engineering Handbook, McGraw Hill, $7^{\text {th }}$ Edition,New York 
Nasution, Arman H. 2006. Manajemen Industri. Yogyakarta: C.V ANDI OFFSET.

Prawirosentono, Suyadi, 2007. Manajemen Operasi (Operations Management) Analisis \& Studi Kasus. PT. Bumi Aksara.

Sugiyono, 2014. Metode Penelitian Kuantitatif, Kualitatif, dan $R \& D$. Bandung: Alfabeta.

Sukirno, Sadono, 2006. Mikro Ekonomi Teori Pengantar Edisi Ketiga.Jakarta: PT. Raja Grafindo Persada. Sunyoto, Danang, 2016. Metodologi Penelitian Akuntansi.PT. Refika Aditama.

Yamit, Zulian, 2003. Manajemen Produksi dan Operasi Edisi Kedua Penerbit EKONISA Fakultas Ekonomi UII Yogyakarta. 